\title{
Mechanisms for co-creation and resources investment in the servitization process
}

\author{
Regina da Silva de Camargo Barros
}

Department of Administration, Federal University of São Paulo, Osasco, Brazil

\begin{abstract}
It is vital to understand servitization from the perspective of cooperation among actors working to co-create value for a service. Thus, this study uses service-dominant to characterize an integrated theory of servitization, especially by including the co-creation mechanism-resource investment relationship in the servitization process. This study incorporates the theories of servitization and service-dominant logic to propose a theoretical model of servitization. A conceptual model was developed wherein servitization comprises three components: actors, mechanisms, and resources. These components are used to build a theoretical model that is divided into phases of implementation. The model uses mechanisms of interaction between actors and their respective resources as crucial components in the efficient implementation of servitization. This study is the first to consider servitization as three components and establish a model. The model affirms that the mechanisms and resources-present in all phases of implementation-are important to the implementation of servitization.
\end{abstract}

Keywords-Co-creation, Logic S-D, Resources, Servitization.

\section{INTRODUCTION}

Servitization, or the provision of services by manufacturers of physical products, is an established field of study (T. S. Baines, Lightfoot, Benedettini, \& Kay, 2009; Vandermerwe \& Rada, 1988). In recent years, research has intensified because an increasing number of organizations are selling more services than goods (Crozet \& Milet, 2014). This trend has made it difficult to draw a stark distinction between the service and manufacturing sectors. The strong drive toward personalization and innovation is driving organizations to improve the provision of additional services. That is, organizations are improving the way the market provides services as well as the integration between goods and services, thereby creating competitive advantages and increasing the value of physical products (Bustinza, Bigdeli, Baines, \& Elliot, 2015; Coreynen, Matthyssens, De Rijck, \& Dewit, 2018; Cusumano, Kahl, \& Suarez, 2015; Fargnoli, Costantino, Di Gravio, \& Tronci, 2018; H. Gebauer, Gustafsson, \& Witell, 2011; Mathieu, 2001; P. Matthyssens \& Vandenbempt, 2010; Park, Geum, \& Lee, 2012; Schmenner, 2009). This process sometimes occurs through the direct involvement of consumers, namely, through co-creation, since consumers play a central role in the design of new services by communicating their needs (Fang, Palmatier, \& Steenkamp, 2008; H. Gebauer et al., 2011; Oliva \&
Kallenberg, 2003; Song \& Sakao, 2017; S.L. Vargo \& Lusch, 2004; Zghidi \& Zaiem, 2017). Services are usually not seen as complementary to an existing product $(\mathrm{H}$. Gebauer, Fleisch, \& Friedli, 2005), but as a value-adding property to meet needs and create mutual value through a co-creation of service and product. If the co-creation process can be considered an important element of the servitization strategy, it is necessary to develop a new service culture in organizations (Ruiz-Alba, Soares, Rodríguez-Molina, \& Frías-Jamilena, 2019).

Increasingly, scholars are interested in the effect of the developing a service provision by the manufacturing sector (Tim Baines et al., 2017; F.H. Beuren, Ferreira, \& Miguel, 2013; Boyer \& Hult, 2005; Lightfoot, Clegg, Prasant, Baines, \& Smart, 2013; Rosenzweig, Laseter, \& Roth, 2011). Studies show that an increase in service intensity can benefit organizations' sales growth and profitability (H. Gebauer et al., 2005; Kohtamaki, Hakala, Partanen, Parida, \& Wincent, 2015; C. Raddats \& Easingwood, 2010; Wise \& Baumgartner, 1999; Zghidi \& Zaiem, 2017). However, other studies report negative results (P. Matthyssens \& Vandenbempt, 2010; Neely, 2008; Spring \& Araujo, 2013; V. Ulaga \& Loveland, 2014) or mixed results (Cheng \& Shiu, 2016; Kastalli \& Van Looy, 2013). Benedettini, Neely, and Swink (2015) show that servitization has a substantial effect on the internal 
bankruptcy risk of manufacturing organizations and increases their exposure to failures. Such findings raise doubts about the effect of servitization on the organization's overall performance and value creation process. This makes in-depth analysis necessary in order to provide useful information about the decisions to be made when integrating services and products.

Servitization research can be traced to Oliva and Kallenberg (2003); its popularity increased after T. S. Baines et al. (2009). Since then, servitization has become synonymous with organizations that moved from selling basic products and services to selling product service systems (PSSs). In response, research has focused on service life cycles and changes in related business models of organizations (Rabetino, Kohtamäki, \& Gebauer, 2017; Rabetino, Kohtamäki, Lehtonen, \& Kostama, 2015; Chris Raddats, Kowalkowski, Benedettini, Burton, \& Gebauer, 2019; Sousa \& Silveira, 2017). Soon, this line of research reoriented itself toward digital business models, the Internet of things, Industry 4.0, and circular economy (Tim Baines \& W. Lightfoot, 2013; Lightfoot et al., 2013; Rabetino, Harmsen, Kohtamäki, \& Sihvonen, 2018). There is now a proliferation of studies in different areas of servitization: unique and complementary perspectives on logic, design and service provision (Malleret, 2006; Oliva \& Kallenberg, 2003; Slack, 2005), service business growth (H. Gebauer, 2008; Martin \& Horne, 1992; Wise \& Baumgartner, 1999), provision of solutions through services (Davies, Brady, \& Hobday, 2006; Galbraith, 2002; Miller \& Hartwick, 2002; Windahl \& Lakemond, 2006), after-sales service marketing (Cohen, Agruwal, \& Agruwal, 2006), profitability of the service (Anderson \& Narus, 1995; Neely, 2008; Samli, Jacobs, \& Wills, 1992), and new business models from servitization (Edvardsson, Holmlund, \& Strandvik, 2008; Lindahl, Sakao, \& Ronnback, 2009). In general, the research is fragmented and even discursive; there is still no clear and inclusive research agenda. These drawbacks, if not overcome through multidisciplinary, broad research, could hinder the adoption of servitization.

Like services, marketing has also updated its focus and perspective over time. The initial emphasis shifted from economic change to marketing management, especially focusing on customer satisfaction (Drucker, 1954; Levitt, 1960). Later, marketing mix (Kotler, 1967) gained importance through the four "Ps" of marketing: product, price, location, and promotion. This expansion added more granularity to the way an organization could adjust its offer in order to satisfy customers, regardless of the forces acting in the market. In 1977, Shostack differentiated service marketing from products (Shostack, 1977). However, products and services were still considered inseparable, although newer research claimed that the sale of a service could generate a longer relationship than the sale of product (Levitt, 1983). It made marketing a relational exchange from the previous transactional exchange, encouraging experts to treat goods and services differently. The studies of Shostack (1977) and Levitt (1983) were precursors to two new marketing trends: service marketing and relationship marketing. Since then, service marketing scholars have argued that the sale of goods and services is different, where services are intangible, heterogeneous, inseparable, and perishable (Fisk, Brown, \& Bitner, 1993).

In their analysis of servitization and service marketing, S.L. Vargo and Lusch (2004) offer an alternative perspective - a paradigm of the services-dominant logic. In this logic, service is developed through an ecosystem of multiple actors (organization, suppliers, consumers, etc.) and based on a relationship. In services, a value is assigned, which is incorporated into the "asset" and transferred as a transaction to the consumer. This perspective is based on the exchange of intangibles, specialized skills, knowledge, and processes. The value (or value proposition) is not simply added or incorporated into production, but co-created and recreated with the organization, customers, and suppliers (social and economic actors) through mechanisms for coordinating a variety of actors with the service (institutions) and through integrated and relational use of resources.

History shows that organizations usually apply the productdominant logic in their operations because the physical product represents the only value in the exchange between a supplier and its customers and that a producer of an asset delivers value in the form of a tangible asset in exchange for client money (Grönroos \& Gummerus, 2014). Robert F. Lusch and Vargo (2014) state that, in the product-dominant logic, value is created by the producer and destroyed by the consumer. It assumes that organizations need to create goods embedded in value and priced higher than the market allows (to maximize profits for the producer in order to be sold); the goods need to be of superior utility compared with the competition.

With the advent of servitization, authors began to analyze the service phenomenon with greater focus and using the dominant logic for marketing. This trend came because service is not only the main category of economic activity in developed countries worldwide, but it is also an interactive process of "doing something for someone," that is, service is valued (Stephen L. Vargo \& Lusch, 2014). In this context, service becomes the unifying objective of any commercial relationship, seen from any perspective, through the acquisition, production, distribution, and 
consumption of resources (Lusch e Vargo 2006). Obviously, this worldview of marketing involves the expansion and reformulation of what, by convention, counts as "service" and is radically opposed to two centuries of the economic-dominant logic used to explain productive capacity. Within this logic, resources (that is, tangible assets and resources) alone do not add value. However, combined with the appropriate skill and knowledge of an actor (organization, supplier, consumer, etc.), resources have value (S.L. Vargo \& Lusch, 2004). In this definition, value is not created on the shop floor, but in conjunction with the consumer. Therefore, value is created through a cooperative relationship between the producer and consumer. Although the phenomenon of servitization is a well-researched topic, this particular view of cooperation has been criticized because of its contradictory nature - that is, value is created through cooperation between producers and consumers, but also by consumers when they enjoy the service. The concept of co-creation has faced scrutiny as well. It is defined more as a metaphor than a concept (Grönroos \& Gummerus, 2014). Here, the organization could be seen as a passive partner, eager to gain consumer trust through close relationships to meet consumer demands (Gronroos, 2008), that is, helping the consumer to increase the value of the product (Brax, 2005).

The service-dominant logic does not explicitly define different spheres of value, but it does so implicitly through a comprehensive value sphere wherein all actors create value together (Robert F. Lusch \& Vargo, 2014). This point-of-view has been debated and, in some cases, the producing organization may be the driving force behind the creation of value. However, in some cases, the consumer has been identified as the driving force for value creation (Grönroos \& Gummerus, 2014). The organizational transition to a service- dominant logic implies a fundamental change. That is, organizations need a change in "mentality," which means the role of organizations must be reviewed externally and internally (Brax, 2005). However, for organizations to start adhering to the servicedominant logic, they need to acquire new knowledge. They must move from knowledge focused on goods to knowledge focused on services. Since resources and institutions exercise their participation in this ecosystem, companies, organizations, and academia must have indepth understanding of how these two elements would work within the ecosystem of value co-creation in the service-dominant logic.

First, as a way of responding to competition, organizations began to develop and expand services to provide their businesses with a new competitive advantage [see $\mathrm{C}$. Raddats and Easingwood (2010), Oliva and Kallenberg
(2003), P. Matthyssens and Vandenbempt (2008)]. Notably, this phenomenon first developed more than 150 years ago during the growth of supply chains (Schmenner, 2009), where manufacturers added services to their servitization offering (Vandermerwe \& Rada, 1988). This was a path of "no return" from products to services (Oliva \& Kallenberg, 2003).

Thus, there is a need for research that contributes to a differentiated reflection of organizations with respect to changing the organizational model, in which service is the item to be exchanged and with the participation of actors, both in the value proposition and in the co-creation service value - performance never seen before in the model with the perspective for the product. However, there is still a knowledge gap because this perspective is new compared with the product-focused perspective. In servitization, there is also a need for market-based analysis using the servicedominant logic wherein all actors, resources, and mechanisms are involved. Value co-creation is an especially interesting concept: By reconnecting production and consumption as an interaction, marketing opportunities form among new groups of "value-taking partners" (Samli et al., 1992) such as producers and consumers. Thus, this study uses service-dominant to characterize an integrated theory of servitization, especially by including the cocreation mechanism-resource investment relationship in the servitization process.

\section{LITERATURE REVIEW}

The marketing literature, organizational studies, and operations management define servitization in several ways. The most popular definitions are from Vandermerwe and Rada (1988), Ren and Gregory (2007), T. S. Baines et al. (2009), and C. Kowalkowski, Persson Ridell, Röndell, and Sörhammar (2012).

Vandermerwe and Rada (1988) state that servitization refers to packages containing combinations of goods, services, support, self-service, and customer-focused knowledge. In contrast, Ren and Gregory (2007) define servitization as a process of change in which manufacturing organizations adopt service orientation and/or develop more and superior services in order to satisfy customer needs. It improves the organization's performance and, consequently, increases competitive advantages. T. S. Baines et al. (2009) consider servitization as the innovation of an organization's resources and processes that create better mutual value through a change from the sale of products to the sale of PSSs. Baines and Lightfoot (2013) divide servitization into three levels of service implementation in organizations: basic, 
intermediate, and advanced services. According to C. Kowalkowski et al. (2012), when an organization changes its business model for servitization, it commits itself to a process of "co-creation of value," indicating that it cannot create value individually; value must be co-created, continuously, in collaboration with customers and partners (R.F. Lusch, Vargo, \& Tanniru, 2010).

In view of this, Macintyre, Parry, and Angelis (2011), Bustinza et al. (2015), and Sanchez, Parry, VendrellHerrero, and Myrthianos (2015) argue that the establishment of bonds with customers and partners becomes fundamental to the process of understanding the need for value creation underlying servitization. In this sense, Carbonell and Rodriguez-Escudero (2014) confirm the importance of customer involvement in the process of co-creating value, which can provide better market performance for the service.

As noted earlier, T. S. Baines et al. (2009) state that servitization is the development of processes and capacities as a natural result of a servitization strategy. It is generated through the co-creation of value. We corroborate this definition by understanding servitization in a business context. We recognize the close collaboration and use of resources for the joint design of services that are co-created to generate mutual value for both parties.

Vendrell-Herrero and Wilson (2017) define a spectrum of current research on servitization using two axes and four quadrants: (1) with conventional approaches to servitization detailed in quadrants I and II and (2) alternative approaches to servitization detailed in quadrants III and IV.

Within the axis of conventional approaches, quadrant I, called the organizational process, is popular in the literature. It contemplates the internal analysis of conventional servitization and analyzes the organizational transformation necessary for the implementation of a service. Studies in this quadrant focus on manufacturers who focus their business on products and production. (T. Baines \& H. Lightfoot, 2013; Cusumano et al., 2015; Vandermerwe \& Rada, 1988). The literature in quadrant II investigates the connection between the implementation of a service and the performance of the organization. It addresses questions on the increase in global competition in manufactured products, obtaining a competitive advantage through the infusion of service, customer satisfaction throughout the product life cycle, and increased risk and decreased flexibility from service implementation (Benedettini et al., 2015; Christian Kowalkowski, Windahl, Kindström, \& Gebauer, 2015; Neely, 2008; Visnjic \& Van Looy, 2013).
In the axis of alternative approaches, quadrant III draws attention to the classic article by Vandermerwe and Rada (1988), who explain that organizations around the world (not only in the manufacturing area) are adding services to their main corporate offering, especially in the context of digitization of resources (later called digital servitization) (Bustinza et al., 2015; Parry, Bustinza, \& VendrellHerrero, 2012; M.E. Porter \& Heppelmann, 2014; M.E. Porter \& Heppelmann, 2015; Schroeder \& Kotlarsky, 2015; Suarez, Cusumano, \& Kahl, 2013). In quadrant IV, an emerging approach to servitization is presented. It involves the interaction of organizations that implement servitization business models through a service of high intellectual added value. These organizations are bridges that interact with manufacturing organizations; they provide services that complement the products of the manufacturer organization. (Czarnitzki \& Spielkamp, 2003; Doloreux \& Shearmur, 2013; Muller \& Zenker, 2001).

It is possible to place the current study in the conventional research axis of servitization, with associations in quadrants I and II. This is because the author analyzes organizational transformation resulting from the implementation of a service but considers elements in the unconventional process in research as well, such as mechanisms and resources of actors.

It is possible to verify that the research on servitization encompasses an inherent change from the traditional transactional exchange (between the organization and the consumer) toward a longitudinal relationship. This change is centered on offerings of hybrid product services that require a review of all the fundamental principles of value creation. Such a move would help reconceptualize value and exchange itself, and this would affect the design as well as implementation of servitization strategies (Tim Baines, Ziaee Bigdeli, Sousa, \& Schroeder, 2020; Bustinza et al., 2015; Smith, Mickey, Dr Nigel Caldwell, Maull, \& C.L. Ng, 2014). To understand further, servitization was initially seen as an extension of manufacturing research based on goods-dominant logic (S.L. Vargo \& Lusch, 2004; Stephen L. Vargo \& Lusch, 2008). Service was only considered complementary to a physical product, increasing the latter's complexity; the value of the service was within the physical product, created, determined, and "added" by the organization (T. S. Baines et al., 2009; Tukker, 2004). Later, servitization literature expanded to studies on service co-created by the client. These studies propose a change in the mentality of the manufacturing approach toward a service-dominant logic $(\mathrm{Ng}$, Maull, \& Yip, 2009; Smith et al., 2014), which focuses on the cocreated value achieved by the customer using the physical 
product; it provides mutual integration of organization and consumer resources (Spohrer \& Maglio, 2008).

Thus, Stephen L. Vargo and Lusch (2008) maintain that the application of resources that maximize value should be the main marketing concern of the organization. Few analyses have been conducted to test the effect of these resources on value. Research on the use of resources is concentrated on classification systems (Madhavaram \& Hunt, 2008), consumer behavior (Arnould, 2005), and conceptual integration of existing knowledge domains, such as innovation theory (Michel, Brown, \& Gallan, 2008). Recent qualitative studies highlight the importance of salespeople personalizing offers and communicating value in specific customer terms (Tuli, Kohli, \& Bharadwaj, 2007; W. Ulaga \& Reinartz, 2011). Thus, there is a need for studies that consider the use of resources not only of the organization providing the service, but of all the actors involved in the process, as an important factor in servitization.

According to Stephen L. Vargo and Lusch (2008), one of the fundamental premises of the service-dominant logic when considering servitization is that merchandise is a distribution mechanism for the provision of services. This premise states that a physical product offer is an indirect provision of services and, therefore, the totality of an organization's offer can be a service. In this offer, the physical product and direct service activities constitute the company's value proposition and allow the company to achieve consumer results (Guo \& Ng, 2011; Ng \& Briscoe, 2012). Through this process, we can achieve the integration of resources and co-creation of value - that is, the important role of consumer competence and the context of use in obtaining the desired results.

The focus on co-creation in the context of use and experience requires a fundamental change in the way organizations design future offerings. Payne et al. (2007) describe this shift as one from a mentality from the insideout to the outside-in value propositions. Rather than basing future offerings on the organization's current competencies (from the inside-out), organizations must first understand the processes of creating value for the consumer and seek to provide greater support for co-creation in these contexts (from the outside-in). This approach is similarly encouraged by Grönroos and Ravald (2011), who claim that understanding a customer's value creation processes allows the organization to design more effective and efficient ways of providing resources that support the cocreation of value, considered to occur through the mutual integration of resources.
Thus, for effective design of service offerings, a manufacturer must consider the availability of the customer's existing resources and the best way to complement them (Jaakkola \& Hakanen, 2013). For this reason, Takeyama, Tsukui, and Shibata (2014) emphasize the importance of recognizing that any resource cannot exist in isolation; instead, it becomes complementary when used to support other resources in the context of customer use (De Gregori, 1987). Ng and Briscoe (2012) explain this by stating that resources are only active in the process of enabling eventual results; they are potential service packages and activities in the process through which can obtain value. In this way, the integration of resources and, by extension, the co-creation of value, is multidirectional; all parties exclusively integrate various resources in relational value creation systems (Frow, Nenonen, Payne, \& Storbacka, 2015; Ng, Parry, Smith, Maull, \& Briscoe, 2012). Thus, S.L. Vargo (2008) suggests that the organization's offer should be seen as an input for the value creation activities that integrate customer resources, and not as its own integration of customer resources for the production of valuable products.

Given the paradigmatic change proposed by the servicedominant logic, this study characterizes servitization from the perspective of this logic. Servitization has been one of the most explored themes, although there is a gap in the inclusion of resources and interaction mechanisms for value co-creation.

This study makes important contributions to academia and industry. Although previous research establishes a conceptual basis and qualitative support for strengthening servitization and the use of resources (individually), this study constitutes, as far as is known, the first exploration of principles in order to unify a theory that prioritizes resources for value co-creation in the service. A second contribution of this study is to provide timely guidance to organizations during the implementation servitization.

\section{THEORICAL FRAMEWORK}

Based on the analysis of the two theories, Fig. 1 describes the conceptual model of this study. Fig. 1 shows the servitization process that will result in a product with the addition of a service or a service itself from the sum of actors (organization, supplier, partner, and consumer), mechanisms, and resources. 


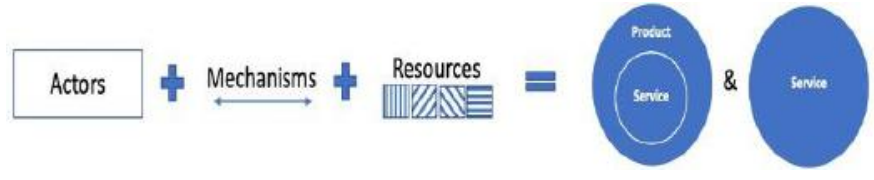

Fig. 1: Servitization process under the service-dominant logic

Source: Author

Fig. 2 details the steps to implement the process shown in Fig. 1, wherein interactions take place through the use of mechanisms with different actors and the use of their respective resources.

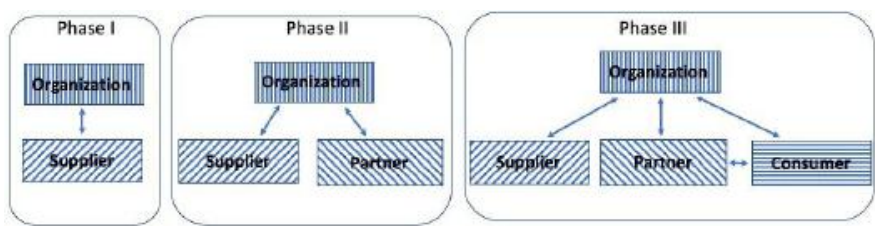

Fig. 2: Implementation phases of the servitization process

Source: Author

Phase I deals with service development and phase II employs the idea of development added to commercialization. In phase III, the contact of the service with the consumer is foreseen. In phase III, continuity is expected, that is, mechanisms and resources are expected to be used without end, so there is continuous co-creation of value.

The servitization process, described in Fig. 1, is based on three elements - actors, mechanisms, and resourceswhich together give rise to a product with added service or a service. The "actors" element come from S. L. Vargo and Lusch (2018), who symbolize entities that have the capacity to act and are normally influenced by institutions (e.g., norms, values, rules, conventions) that limit or restrict these actions. To S. L. Vargo and Lusch (2018), the mechanisms refer to rules, norms, meanings, symbols, and similar communication as well as collaboration and decision-making aids that enable the creation of value. These mechanisms exist as part of more comprehensive institutional arrangements for coordinating the integration of resources and exchange services and similar value creation activities. The resources, included in the model, tangible or intangible, are seen as the source of the provision of services. They are used by the actors to increase the value of well-being, following the classification of operand (static and tangible; requiring other resources to act on them to provide benefits) and operational (intangible and dynamic; as knowledge and skills, they are usually able to act on other [potential] resources to create benefits) (S. L. Vargo \& Lusch, 2018).
The result of the integration of the three elements is shown in the model (see Fig. 1) as "Product with added service" and "Service." For the process implementation in Fig. 1, it is necessary to implement the process phases, outlined in Fig. 2. Further, it is necessary to identify mechanisms and resources as well, since they are two of the three elements required for the conceptual model to be implemented as expected. However, for this process to occur in an integrated manner, it is necessary to comply with each of its three phases.

Phase I considers the beginning of the development of the product and/or service. This takes place through a mechanism existing between the organization and supplier and the application of resources. In this first phase, service becomes the unifying objective of any business relationship seen from any perspective. This unification occurs through the acquisition, production, distribution and consumption of resources, both by the organization and the partner, (R. F. Lusch \& Vargo, 2006) and combined with the appropriate skill and knowledge of an actor; altogether, they have value (S.L. Vargo \& Lusch, 2004).

In phase II, this product and/or service already has a value proposal carried out jointly, but it needs further increase, considering partners involved in the exchange process.

In phase III, this product and/or service is already on the market. The participation in increasing its value remains with the same group and with the participation of the consumer, who carries out interactions both with the organization and with the partners involved in the process. However, in this model, the view of marketing on an emerging business model is contemplated. The key areas for servitization to occur effectively are identified, that is, the mechanism of interaction with the aid of mutual resources. This model has a distinction: the insertion of all elements that are considered necessary by the theory of servitization. In addition, it incorporates the theory of marketing, which considers the service the main market item.

This model above can assist organizations in (1) deciding to adopt this business model as well as (2) implementing and (3) maintaining it. Many studies analyze the organizational change that must be implemented when adopting this model. However, the approach of the items that make up the model and their effect on the model's ecosystem is not frequently addressed in the literature.

As an academic study, this model contributes by integrating the theory of servitization with an emerging theory in marketing. This way, it unifies a process for proper implementation in organizations. This contributes to 
the introduction of new perspectives on the theory of servitization and at the same time adds questions about assumptions and synergies from different theories and areas of knowledge.

\section{RESEARCH CONTEXT}

According to Kim, Cohen, and Netessine (2007), organizations that have adapted to servitization have achieved good results. An example of this is General Motors, which, in 2003, earned US\$ 9 billion in after-sales revenue generated by services that generated US $\$ 2$ billion in profits. This figure is higher than the profit achieved from the US\$ 150 billion revenue in car sales in the same period. A second report is from a UK survey of 33 executives from 28 organizations of different sizes and who started their servitization processes. T. Baines and Shi (2015) found an increase of 5-10\% in the business of these organizations and their customers reduced their costs by $25-30 \%$.

According to T. Baines and H. Lightfoot (2013), the participation of services in the profitability of servitized organizations is relevant. Table I shows the relationship between the profit margins generated between the manufacture of products and the provision of services in organizations in different sectors in the US during 2010. As it turns out, there are much more relevant margins in the provision of services, with ratios of up to 3.8 .

Table.1: Relationship between profit margins for services and products

Source: Baines and Lightfoot (2013b)

\begin{tabular}{cccc}
\hline SECTOR & $\begin{array}{c}\text { PROFIT MARGIN } \\
\text { PRODUCT } \\
\text { MANUFACTURING }\end{array}$ & $\begin{array}{c}\text { PROFIT MARGIN } \\
\text { PROVISION OF } \\
\text { SERVICES }\end{array}$ & $\begin{array}{c}\text { RELATION } \\
\text { SERVICE/PRODUCT }\end{array}$ \\
\hline $\begin{array}{c}\text { Printing industry } \\
\text { machines }\end{array}$ & $3,4 \%$ & $13,1 \%$ & 3,8 \\
$\begin{array}{c}\text { Machine tools } \\
\text { Power equipments }\end{array}$ & $5,3 \%$ & $8,9 \%$ & 1,67 \\
Railway Industry & $7 \%$ & $9,9 \%$ & 1,4 \\
\hline
\end{tabular}

Because of the level of socioeconomic importance of services, researchers focus on the generation of design methods and tools for the development of servitization. However, options on how to use these methods and tools concretely in the design process are rare, with successive recommendations to build a body of knowledge that addresses this gap in the literature (Alvarez, 2012; Clayton, Backhouse, \& Dani, 2012; Marilungo, Peruzzini, \& Germani, 2015; Pawar, Beltagui, \& Riedel, 2009). W. Reim, Parida, and Örtqvist (2015) also recognized this gap, stating that suggestions on how organizations can adopt and implement business models focused on servitization are limited. They claim a negligence in the fundamentals to implement business models focused on servitization.

Notably, there is a glaring absence of quantitative results in research on servitization; there are limitations in the tools and methods as well. These lacunae would require contributions from scholars with diverse expertise when dealing with implementation of servitization in practice. Evidently, this topic is still not widely disseminated in the academic community, which makes its practical implementation even more complex (Tim Baines et al., 2017; F. H. Beuren, Ferreira, Zancul, \& Miguel, 2014).

Among the methods of implementing servitization most cited in the literature, Braga Júnior (2017) identify four types: service-oriented PSS development process, generic design methodology, PSS design methodology, and methodology for developing PSSs. However, each has limitations.

Service-oriented PSS development process foresees the participation of two different entities (the service provider and the product manufacturing organization) that perform phases in an isolated way or together, depending on the development phase. This separation between product and service suppliers is a striking feature of this method. However, this feature makes its applicability restricted to cases in which products are means for the execution of services and not an equivalent value for the customer.

In generic design methodology for different types of PSS, stakeholder participation (user, business model, and organizational structure) is considered in all phases of the development process in order to ensure compliance with project requirements. However, an in-depth strategic analysis of the market is not observed for the operation of servitization.

In PSS design methodology, the objective is to design the physical objects involved in servitization when considering relationships with other objects and service units. This method has different because it specifies the engineering criteria for the product. This emphasis is interesting in situations where the product is complex. On the other hand, the method does not analyze the business context in which servitization will be applied.

Methodology for developing PSSs focuses on creating new servitization offers. It was designed to provide a group of tools that enable the development of new models of servitization. It seeks to offer satisfaction to the client and minimize environmental and social effects. It is focused on the development of the system and is less concerned about product and service development. 
Although all the methods covered have their scientific and social contribution, none provides for the participation of actors, mechanisms, and resources in co-creation of value. The model suggested in this study, through the integration of servitization and marketing theories, has greater potential for academic and social contributions.

\section{METHODOLOGY}

The analysis (see Figure 1) is based on the crucial elements for the implementation of servitization (which will result in a product with an added service or a service itself), namely, the actors, mechanisms, and resources. However, for the functioning of model I, it is necessary to implement model II, which comprises three different phases, along with the different forms of the three stated elements.

According to Eisenhardt (1989), the development of models and/or theories is the central activity of researchers. Traditionally, many authors have developed models and/or theories by combining observations from the literature, common sense, and experience. However, this, in many situations, leads to tenuous distortions of the empirical reality of the researched objects.

For this study, the aim was to demonstrate the possibility of integrating two theories to (1) solve research gaps and (2) promote different studies in the field of servitization. Together, they promote different contributions from points by sight. Thus, the study analyzes research on servitization - its applicability and depth in relation to the integration of different theories as well as its practical applicability for organizations.

\section{FINDINGS}

This study provides theoretical contributions to the emerging service literature. The literature on servitization highlights the need to focus on different strategic initiatives to deal with the transition from transactional business models to models based on relationships between actors, which is necessary for advanced service delivery (Oliva \& Kallenberg, 2003). This study emphasizes in its model that the relationship with the actors is a crucial item for the process of servitization.

The literature highlights the importance of organizational structures and individual factors in services. However, it does not address the critical role of the service network and its interaction (Kucza \& Gebauer, 2011). Thus, studies are needed that consider the full range of service network challenges that contribute to service generation (Durugbo \& Riedel, 2013; Hakanen, Helander, \& Valkokari, 2017; C. Kowalkowski, Kindström, \& Brehmer, 2011; Tabibzadeh
$\&$ Wireman, 2003). Thus, this study focuses on advancing the understanding of mechanisms among actors in the service network that is responsible for the implementation of servitization.

Some studies consider the development and delivery of a solution as the effort of a single organization or neglected the role of suppliers (Paiola, Saccani, Perona, \& Gebauer, 2013; Visintin, 2012). Few studies consider using third parties to provide services in service environment [e.g., Mathieu (2001); Davies, Brady, and Hobday (2007); Nordin (2008); C. Kowalkowski et al. (2011)]. Only recently have studies explicitly dealt with the supplier relation in servitization (Bastl, Johnson, Lightfoot, \& Evans, 2012; Durugbo \& Riedel, 2013; Finne \& Holmström, 2013; Lockett, Johnson, Evans, \& Bastl, 2011; Paiola et al., 2013; Saccani, 2012). This study proposes the integration of the actors (not just the supplier) in the whole process of servitization.

Finne and Holmström (2013) and Kohtamäki, Rabetino, and Möller (2018) studied relationships in a servitized context, analyzing the role of the actors accompanied by their capabilities and resources together in order to lead to an effective service delivery. However, Lockett et al. (2011) show that the relationship between actors and resources in service environments is characterized by greater complexity compared with the "traditional" supply chain of manufacturing. Hence, while there is research being initiated, it is still incipient. Thus, further investigations that are more unified with respect to the servitization process are required.

Studies show the dynamic nature of the life cycle of the relationship among actors, which requires reciprocal adjustments (Ferreira, Proença, Spencer, \& Cova, 2013; H. Gebauer et al., 2011; Sjödin, Parida, \& Kohtamäki, 2016; Sjödin, Parida, \& Wincent, 2016). It is possible that these adjustments are critical for the actors of the service network. An example of this is the variation, from country to country, in the segments and needs of customers involved in the servitization process. This variation can create major managerial and operational challenges for the partners involved, who will then have to deal with different customer characteristics and incentive models and establish new partnerships with the actors in the value chain. (Legnani \& Cavalieri, 2009; Pawar et al., 2009).

Among the factors Zarpelon Neto, Pereira, and Borchardt (2015) point as barriers in the relationship with partners are local regulations, resource allocation, internal culture, commercial viability, and lack of knowledge. Thus, the understanding of the risk, and the complexity associated with the relationship among actors, needs greater 
clarification (C. Kowalkowski et al., 2011; Wiebke Reim, Parida, \& Sjödin, 2016; Wilson, 1999). Although the risks of implementing servitization are highlighted, the literature also reports the positive aspects. These positive aspects are attributed to the more complex and comprehensive offer that includes services in its portfolio (with coordination costs and increased operational risks). Thus, the new economic incentives foster a complete transition in all organizational dimensions (Nordin, Kindström, Kowalkowski, \& Rehme, 2011).

Ideas for service innovations can come from various sources, such as customers, suppliers, and partners. However, at the stage of developing a new service, new ideas are selected. The chosen concepts are developed and tested in order to verify their viability. Then, the concepts that overcome the developmental obstacles are taken to the "analysis" stage in order to determine their potential. At the same time, time and money are invested as part of a venture that is expected to be profitable (Fitzsimmons, 2010).

In this phase, a supplier, as an actor, should be directly involved in the process in order to contribute to the initial design of the service. This mutual contribution will depend on resources (whether tangible or intangible). For the design to be created, certain mechanisms that promote the relationship among the actors should be put into practice.

Phase I of the implementation of the servitization process presents some challenges, such as, for example, ethics and the commitment of the involvement of the two actors in the process. This can lead to a strengthening of the relationship through the interaction mechanisms between the actors. On the other hand, it can strain the relationship, especially by non-agreement in ideas or uneven investment of resources.

Phase II is marked by more intense interaction mechanisms, as the initial idea has already been developed and, at that moment, it materializes with the analysis of commercial viability and participation of partners. In phase I, the organization and supplier developed the idea of the service, so phase II will require an increased investment from the organization for the creation of the so-called "prototype" or a test of how this service will be implemented.

The supplier in phase II is responsible for analyzing which items and processes will be necessary to materialize the idea in phase I. Also, a new participant is included in the implementation: the partner. As an expert on the idea of the service to be implemented, it will involve the partner's resources (including market expertise) as a contribution to the creation of the service.
The interaction mechanisms used in this phase will be intense, as the service idea is materialized, necessary adjustments made, and processes that meet the initial proposal are executed and fulfilled. However, there may be conflicts of interest in this co-creation process because of the continuous investment of resources.

Phase III is characterized by the intensity in the most discussed mechanisms of interaction. This is because, in addition to the actors involved in the previous phases, the participation of the consumer, for whom the service is created, is inserted.

After the adjustments made in phase II, the organization, together with the supplier, presents the "prototype" or a service test. Partners are delegated participation in the forms of marketing or access to the service for the consumer.

The greater the involvement of consumers in the production of the service, the greater their potential to influence the processes in which they are engaged. Some researchers argue that organizations should view consumers as partial employees who can influence the productivity and quality of service processes and results. This influence by theoretical and practical knowledge in relation to the service can be seen as an investment of consumer resources (Lovelock \& Wright, 2002).

The mechanisms for interaction in phase III must be defined, as it is a phase that involves pre-tests or a preexperience of the consumer with the service. Especially, the perspective presented in phase III requires a change in the managerial mentality of the organization, supplier, and partner actors. This will be required as consumers are given the opportunity to participate at an active level in the service. Their own involvement in the co-creation process would make them more likely to be satisfied.

The two models in this study present mechanisms and resources as crucial for the implementation of servitization. In the three phases, the interaction between the actors and the investment of resources may occur simultaneously. In the implementation, it is important that each phase is correctly followed, with the corresponding involvement of the respective actors, obeying the hierarchy of the implementation phases.

\section{CONCLUSION}

The implication that model I produces is the integration of the servitization theory with the dominant marketing logic theory, providing a view of the process from beginning to end. In its implementation, it is possible to identify the 
organizational change necessary to adapt the servitization business model, in processes divided by the three phases.

Phase I integrates the two actors through interaction mechanisms that are not predetermined in the model. Phase II involves the interaction of two previous actors in phase I and the partner. This phase defines the service within the business model to market to the consumer. In phase III, the consumer is introduced in the implementation of the process. The consumer can participate in the initial prototyping phase of the service and have a pre-experience of its use. This phase has greater implications because it is a paradigm shift to include the consumer in the service value proposal.

This study has social implications, as it includes as actors the organization, supplier, partner, and consumer in the same process along with the responsibilities and investment of resources. For the services area, this study addresses a lacuna in extant research on the implementation of servitization from the perspective of marketing. It includes the actors in an integrated way in the project of development and implementation of services, united by the mechanisms of interaction and resources. For the theory of servitization, combination of theories and views is promoted to map the implementation of servitization in a procedural, sectorized, and hierarchical way.

\section{FUTURE RESEARCH}

It is suggested that scholars must analyze the mechanisms of interaction among actors, who are crucial. However, no studies exist that indicate the characteristics, levels, and degrees of these mechanisms, so they are applied effectively in the servitization processes. In addition, studies that analyze the identification, selection, and implementation of actors' resources for the servitization process could be important proposals. For the services area, future studies should characterize the implementation of servitization and the assessment of the relationship by level of importance, of mechanisms of interaction, and of investment of resources in the co-creation of service value.

\section{REFERENCES}

[1] Alvarez, R. L. P. (2012). Uma proposta de modelo de maturidade aplicada à servitização de empresas de bens de consumo duráveis. (Doutorado). Universidade de São Paulo, São Paulo/SP.

[2] Anderson, J., \& Narus, J. (1995). Capturing the value of supplementary services. Harvard Business Review, January-February, 75-836.
[3] Arnould, E. (2005). Animating the big middle. Journal of Retailing, 81(2), 89-96.

[4] Baines, T., \& Lightfoot, H. (2013). Made to Serve: How Manufacturers Can Compete through servitization and Product Service Systems. Hoboken, NJ.: John Wiley \& Sons.

[5] Baines, T., \& Lightfoot, H. (2013b). Made to Serve: how manufacturers can competethrough servitization and product-service-system. West Sussex: John Wiley \& Sons.

[6] Baines, T., \& Shi, V. G. (2015). A Delphi study to explore the adoption of servitization in UK companies. Production Planning \& Control, 26(14-15), 1171-1187.

[7] Baines, T., \& W. Lightfoot, H. (2013). Servitization of the manufacturing firm. International Journal of Operations \& Production Management, 34(1), 2-35. doi:10.1108/ijopm-02-2012-0086

[8] Baines, T., Ziaee Bigdeli, A., Bustinza, O. F., Shi, V. G., Baldwin, J., \& Ridgway, K. (2017). Servitization: revisiting the state-of-the-art and research priorities. International Journal of Operations \& Production Management, 37(2), 256-278. doi:10.1108/ijopm-062015-0312

[9] Baines, T., Ziaee Bigdeli, A., Sousa, R., \& Schroeder, A. (2020). Framing the servitization transformation process: A model to understand and facilitate the servitization journey. International Journal of Production Economics, 221 , 107463.

doi:https://doi.org/10.1016/j.ijpe.2019.07.036

[10] Baines, T. S., Lightfoot, H. W., Benedettini, O., \& Kay, J. M. (2009). The servitization of manufacturing: a review of literature and reflection on future challenges. J. Manuf. Technol. Manag., 20(5), 547-567.

[11] Bastl, M., Johnson, M., Lightfoot, H., \& Evans, S. (2012). Buyer-supplier relationships in a servitized environment: an examination with Cannon and Perreault's framework. International Journal of Operations and Production Management, 32(6), 650-675.

[12] Benedettini, O., Neely, A., \& Swink, M. (2015). Why do servitized firms fail? A risk-based explanation. . Int. J. Oper. Prod. Manag., 35(6), 946-979.

[13] Beuren, F. H., Ferreira, M. G. G., \& Miguel, P. A. C. (2013). Product-service systems: a literature review on integrated products and services. J. Clean. Prod., 47(5), 222-231.

[14] Beuren, F. H., Ferreira, M. G. G., Zancul, E. S., \& Miguel, P. A. (2014). Análise de conteúdo de publicações em Sistemas Produto-Serviço. . Produção Online, 14(1), 31-57.

[15] Boyer, K., \& Hult, G. (2005). Extending the supply chain: integrating operations and marketing in the online grocery industry. J. Oper. Manag., 23(6), 642-661.

[16] Braga Júnior, A. E. (2017). Sistema Produto-Serviço e Servitização: Pesquisa-Ação em uma empresa de manufatura Engineer to Order (Doutorado). Universidade Federal de São Carlos, São Carlos - SP. 
[17] Brax, S. A. (2005). A manufacturer becoming service provider - Challenges and a paradox. Journal of Service Theory and Practice 15(2), 142-155.

[18] Bustinza, O. F., Bigdeli, A. Z., Baines, T., \& Elliot, C. (2015). Servitization and competitive advantage: the importance of organizational structure and value chain position. Res. Technol. Manag., 58(5), 53-60.

[19] Carbonell, P., \& Rodriguez-Escudero, A. (2014). Antecedents and consequences of using information from customers involved in new service development. Journal of Business \& Industrial Marketing, 29(2), 112-122.

[20] Cheng, C. C. J., \& Shiu, E. (2016). Examining the link between service modularity and firm performance: a capability perspective. . J. Serv. Theor. Pract. , 26(5), 696-720.

[21] Clayton, R. J., Backhouse, C. J., \& Dani, S. (2012). Evaluating existing approaches to product-service system design: A comparison with industrial practice. Journal of Manufacturing Technology Management, 23(3), 272-298.

[22] Cohen, M., Agruwal, N., \& Agruwal, V. (2006). Winning in the aftermarket. Harvard Business Review, May, 131138.

[23] Coreynen, W., Matthyssens, P., De Rijck, R., \& Dewit, I. (2018). Internal levers for servitization: how productoriented manufacturers can upscale product-service systems. Int. J. Prod. Res., 56(2), 2184-2198.

[24] Crozet, M. D., \& Milet, E. (2014). The servitization of French manufacturing firms. Paper presented at the CEPII research center.

[25] Cusumano, M. A., Kahl, S. J., \& Suarez, F. F. (2015). Services, industry evolution, and the competitive strategies of product firms. Strat. Manag. J. , 36(4), 559575.

[26] Czarnitzki, D., \& Spielkamp, A. (2003). Business services in Germany: bridges for innovation. The Service Industries Journal, 23(2), 1-30.

[27] Davies, A., Brady, T., \& Hobday, M. (2006). Charting a path towards integrated solutions. MIT Sloan Management Review, 47(3).

[28] Davies, A., Brady, T., \& Hobday, M. (2007). Organizing for solutions: systems seller vs. systems integrator. Industrial Marketing Management 36(2), 183-193.

[29] De Gregori, T. (1987). Resources are not; they become: an institutional theory. J. Econ.(21(3)), 1241-1263.

[30] Doloreux, D., \& Shearmur, R. (2013). Innovation strategies: are KIBS just another source of information? Industry and Innovation, 20(8), 719-738.

[31] Drucker, P. (1954). The Practice of Management. New York, NY.: Harper and Row.

[32] Durugbo, C., \& Riedel, J. C. (2013). Readiness assessment of collaborative networked organisations for integrated product and service delivery. International Journal of Production Research, 51(2), 598-613.

[33] Edvardsson, B., Holmlund, M., \& Strandvik, T. (2008). Initiation of business relationships in service-dominant settings. Industrial Marketing Management,, 37(3), 339350 .
[34] Eisenhardt, K. M. (1989). Building theories from case study research. . Academy of management review, 14(4), 532-550.

[35] Fang, E., Palmatier, R., \& Steenkamp, J. (2008). Effect of service transition strategies on firm value. J. Market., 72(5), 1-14.

[36] Fargnoli, M., Costantino, F., Di Gravio, G., \& Tronci, M (2018). Product service-systems implementation: a customized framework to enhance sustainability and customer satisfaction. . J. Clean. Prod. , 188, 387-401.

[37] Ferreira, F. N. H., Proença, J. F., Spencer, R., \& Cova, B. (2013). The transition from products to solutions: External business model fit and dynamics. Industrial Marketing Management Science, 42(7), 1093-1101.

[38] Finne, M., \& Holmström, J. (2013). A manufacturer moving upstream: triadic collaboration for service delivery. . Supply Chain Management: An International Journal, 18(1), 21-33.

[39] Fisk, R., Brown, S., \& Bitner, M. (1993). Tracking the evolution of the services marketing literature. Journal of Retailing, 69(1), 61-103.

[40] Fitzsimmons, J. A. (2010). Administração de Serviços: Operações, estratégia e tecnologia da informação (Vol. 6ed.). Porto Alegre: Bookman.

[41] Frow, P., Nenonen, S., Payne, A., \& Storbacka, K. (2015). Managing co-creation design: a strategic approach to innovation. Br. J. Manag., 26, 463-483.

[42] Galbraith, J. (2002). Organising to deliver solutions. Organizational Dynamics, 13(2), 194-207.

[43] Gebauer, H. (2008). Identifying service strategies in product manufacturing companies by exploring environment strategy considerations. Industrial Marketing Management, 37, 278-291.

[44] Gebauer, H., Fleisch, E., \& Friedli, T. (2005). Overcoming the service paradox in manufacturing companies. European Management Journal, 23(1), 14-26.

[45] Gebauer, H., Gustafsson, A., \& Witell, L. (2011). Competitive advantage through service differentiation by manufacturing companies. J. Bus. Res., 64(12), 12701280 .

[46] Gronroos, C. (2008). Service Logic Revisited: Who Creates Value? And Who Co-Creates? European Business Review, 20, 298-314.

[47] Grönroos, C., \& Gummerus, J. (2014). The service revolution and its marketing implications: service logic vs service-dominant logic. Managing Service Quality: An International Journal, 24(3), 206-229.

[48] Grönroos, C., \& Ravald, A. (2011). Service as business logic: implications for value creation and marketing. $J$. Serv. Manag. , 22(1), 5-22.

[49] Guo, L., \& Ng, I. (2011). The co-production of equipment-based services: an interpersonal approach. European Manag. J., 29(1), 43-50.

[50] Hakanen, T., Helander, N., \& Valkokari, K. (2017). Servitization in global business-to-business distribution: The central activities of manufacturers. Industrial Marketing Management Science, 63, 163-178. 
[51] Jaakkola, E., \& Hakanen, T. (2013). Value co-creation in solution networks. Ind. Mark. Manag. , 42(1), 47-58.

[52] Kastalli, I. V., \& Van Looy, B. (2013). Servitization: disentangling the impact of service business model innovation on manufacturing firm performance. J. Oper. Manag. , 31(4), 169-180.

[53] Kim, S. H., Cohen, M. A., \& Netessine, S. (2007). Performance Contracting in After-Sales Service Supply Chains. Management Science, 53(12), 1843-1858.

[54] Kohtamaki, M., Hakala, H., Partanen, J., Parida, V., \& Wincent, J. (2015). The performance impact of industrial services and service orientation on manufacturing companies. J. Serv. Theor. Pract., 25(4), 463-485.

[55] Kohtamäki, M., Rabetino, R., \& Möller, K. (2018). Alliance capabilities: A systematic review and future research directions. Industrial Marketing Management, 68 ,

188-201.

doi:https://doi.org/10.1016/j.indmarman.2017.10.014

[56] Kotler, P. (1967). Marketing Management Planning and Control. Upper Saddle River, NJ.: Prentice-Hall.

[57] Kowalkowski, C., Kindström, D., \& Brehmer, P. O. (2011). Managing industrial service offerings in global business markets. Journal of Business \& Industrial Marketing, 26(3), 181-192.

[58] Kowalkowski, C., Persson Ridell, O., Röndell, J. G., \& Sörhammar, D. (2012). The co-creative practice of forming a value proposition. Journal of Marketing Management, 28(13/14), 1553-1570.

[59] Kowalkowski, C., Windahl, C., Kindström, D., \& Gebauer, H. (2015). What service transition? Rethinking established assumptions about manufacturers' service-led growth strategies. Industrial Marketing Management, 45, 59-69. doi:10.1016/j.indmarman.2015.02.016

[60] Kucza, G., \& Gebauer, H. (2011). Global approaches to the service business in manufacturing companies. Journal of Business \& Industrial Marketing, 26(7), 472-483.

[61] Legnani, E., \& Cavalieri, S. (2009). Exploring the causal relationships of KPIs in after sales service systems. Paper presented at the FIP international conference on advances in production management systems, Berlin, Heidelberg.

[62] Levitt, T. (1960). Marketing myopia. Harvard Business Review, 38(4), 138-149.

[63] Levitt, T. (1983). After the sale is over. Harvard Business Review, 61(5), 87-93.

[64] Lightfoot, H., Clegg, J. M., Prasant, B., Baines, T., \& Smart, P. (2013). The servitization of manufacturing. International Journal of Operations \& Production Management, 33(11/12), 1408-1434. doi:10.1108/ijopm07-2010-0196

[65] Lindahl, M., Sakao, T., \& Ronnback, A. (2009). Business implications of integrated product and service offerings. Paper presented at the 1st CIRP (IPS2) Conference, Cranfield.

[66] Lockett, H., Johnson, M., Evans, S., \& Bastl, M. (2011). Product service systems and supply network relationships: an exploratory case study. Journal of Manufacturing Technology Management 22(3), 293-313.
[67] Lovelock, C., \& Wright, L. (2002). Serviços: Marketing e Gestão. São Paulo: Saraiva.

[68] Lusch, R. F., \& Vargo, S. L. (2006). Service-dominant logic: reactions, reflections and refinements. Marketing Theory, 6(3), 281-288.

[69] Lusch, R. F., \& Vargo, S. L. (2014). Service-dominant logic: Premises, perspectives, possibilities. Cambridge University Press.

[70] Lusch, R. F., Vargo, S. L., \& Tanniru, M. (2010). Service, value networks and learning. Journal of the Academy of Marketing Science, 38(1), 19-31.

[71] Macintyre, M., Parry, G., \& Angelis, J. (2011). Service Design and Delivery. New York, NY.: Springer.

[72] Madhavaram, S., \& Hunt, S. D. (2008). The servicedominant logic and a hierarchy of operant resources: developing masterful operant

[73] resources and implications for marketing strategy. Journal of the Academy of Marketing Science, 36(1), 67-82.

[74] Malleret, V. (2006). Value creation through service offers. European Management Journal, 24(1), 106-116.

[75] Marilungo, E., Peruzzini, M., \& Germani, M. (2015). An Integrated Method to Support PSS Design within the Virtual Enterprise. Procedia CIRP, 30, 54-59.

[76] Martin, C., \& Horne, D. (1992). Restructuring towards a service orientation: the strategic challenges. International Journal of Service Industry Management, 3(3), 25-38.

[77] Mathieu, V. (2001). Service strategies within the manufacturing sector: benefits, costs and partnership. Int. J. Serv. Ind. Manag. , 12(5), 451-475.

[78] Matthyssens, P., \& Vandenbempt, K. (2008). Moving from basic offerings to value-added solutions: strategies, barriers, and alignment. Industrial Marketing Management, 37(3), 316-328.

[79] Matthyssens, P., \& Vandenbempt, K. (2010). Service addition as business market strategy: identification of transition trajectories. J. Serv. Manag., 21(5), 693-714.

[80] Michel, S., Brown, S. W., \& Gallan, A. S. (2008). An expanded and strategic view of discontinuous innovations: deploying a service-dominant logic. Journal of the Academy of Marketing Science, 36(1), 54-66.

[81] Miller, D., \& Hartwick, J. (2002). The problem of solutions: balancing clients and capabilities. Business Horizons, March/April, 3-12.

[82] Muller, E., \& Zenker, A. (2001). Business services as actors of knowledge transformation: the role of KIBS in regional and national innovation systems. Research Policy, 30, 1501-1516.

[83] Neely, A. (2008). Exploring the financial consequences of the servitization of manufacturing. Oper. Manag. Res., l(2), 103-118

[84] Ng, I. C. L., \& Briscoe, G. (2012). Value, variety and viability: new business models for co-creation in outcome-based contracts. Int. J. Serv. Sci., 3(3), 26-48.

[85] Ng, I. C. L., Maull, R., \& Yip, N. (2009). Outcome-based contracts as a driver for systems thinking and servicedominant logic in service science: evidence from the defence industry. Eur. Manag. J., 27(6), 377-387. 
[86] Ng, I. C. L., Parry, G., Smith, L., Maull, R., \& Briscoe, G. (2012). Transitioning from a goods-dominant to a servicedominant logic: visualising the value proposition of RollsRoyce. J. Serv. Manag., 23(3), 416-439.

[87] Nordin, F. (2008). Linkages between service sourcing decisions and competitive advantage: a review, propositions, and illustrating cases. . International Journal of Production Economics, 114, 40-55.

[88] Nordin, F., Kindström, D., Kowalkowski, C., \& Rehme, J. (2011). The risks of providing services: Differential risk effects of the service-development strategies of customisation, bundling and range. Journal of Service Management, 22(3), 390-408.

[89] Oliva, R., \& Kallenberg, R. (2003). Managing the transition from products to services. International Journal of Service Industry Management, 14(2), 160-172. doi:10.1108/09564230310474138

[90] Paiola, M., Saccani, N., Perona, M., \& Gebauer, H. (2013). Moving from products to solutions: strategic approaches for developing capabilities. European Management Journal, 31(4), 390-409.

[91] Park, Y., Geum, Y., \& Lee, H. (2012). Toward integration of products and services: taxonomy and typology. J. Eng. Technol. Manag. , 29(4), 528-545.

[92] Parry, G., Bustinza, O. F., \& Vendrell-Herrero, F. (2012). Servitisation and value co-production in the UK music industry: an empirical study of consumer attitudes. International Journal of Production Economics, 135(1), 320-332.

[93] Pawar, K. S., Beltagui, A., \& Riedel, J. C. K. H. (2009). The PSO triangle: designing product, service and organisation to create value. International Journal of Operations \& Production Management, 29(5), 468-493.

[94] Porter, M. E., \& Heppelmann, J. E. (2014). How smart, connected products are transforming competition. Harvard Business Review, 92(11), 11-64.

[95] Porter, M. E., \& Heppelmann, J. E. (2015). How smart, connected products are transforming companies. Harvard Business Review, 93(10), 1-19.

[96] Rabetino, R., Harmsen, W., Kohtamäki, M., \& Sihvonen, J. (2018). Structuring servitization-related research. International Journal of Operations \& Production Management, 38(2), 350-371. doi:10.1108/ijopm-032017-0175

[97] Rabetino, R., Kohtamäki, M., \& Gebauer, H. (2017). Strategy map of servitization. International Journal of Production Economics, 192, 144-156. doi:10.1016/j.ijpe.2016.11.004

[98] Rabetino, R., Kohtamäki, M., Lehtonen, H., \& Kostama, H. (2015). Developing the concept of life-cycle service offering. Industrial Marketing Management, 49, 53-66. doi:10.1016/j.indmarman.2015.05.033

[99] Raddats, C., \& Easingwood, C. (2010). Services growth options for B2B product-centric businesses. Ind. Market. Manag. , 39(8), 1334-1345.

[100] Raddats, C., Kowalkowski, C., Benedettini, O., Burton, J., \& Gebauer, H. (2019). Servitization: A contemporary thematic review of four major research streams. Industrial Marketing Management, 83, 207-223. doi:https://doi.org/10.1016/j.indmarman.2019.03.015

[101] Reim, W., Parida, V., \& Örtqvist, D. (2015). ProductService Systems (PSS) business models and tactics - a systematic literature review. Journal of Cleaner Production, 97(61-75).

[102] Reim, W., Parida, V., \& Sjödin, D. R. (2016). Risk management for product-service system operation. International Journal of Operations \& Production Management, 36(6), 665-686. doi:10.1108/ijopm-102014-0498

[103] Ren, G., \& Gregory, M. J. (2007). Servitization in manufacturing companies: a conceptualization, critical review, and research agenda. Paper presented at the Frontiers in Service Conference, San Francisco.

[104] Rosenzweig, E. D., Laseter, T. M., \& Roth, A. V. (2011). Through the service operations strategy looking glass: influence of industrial sector, ownership, and service offerings on B2B e-marketplace failures. J. Oper. Manag., 29(1), 33-48.

[105] Ruiz-Alba, J. L., Soares, A., Rodríguez-Molina, M. A., \& Frías-Jamilena, D. M. (2019). Servitization strategies from customers' perspective: the moderating role of cocreation. Journal of Business \& Industrial Marketing, 34(3), 628-642. doi:10.1108/jbim-02-2017-0028

[106] Saccani, N. (2012). Servitization strategies and sourcing decisions for product services: an exploratory study. International Journal of Industrial and Systems Engineering, 10(3), 336-354.

[107] Samli, A., Jacobs, L., \& Wills, J. (1992). What pre-sale and post-sale services do you need to be competitive. Industrial Marketing Management, 21, 33-42.

[108] Sanchez, B. O., Parry, G., Vendrell-Herrero, F., \& Myrthianos, V. (2015). Link channels or how to enhance upstream-downstream relations in servitized contexts. Dyna Management [In Press]

[109] Schmenner, R. W. (2009). Manufacturing, service, and their integration: some history and theory. Int. J. Oper. Prod. Manag., 29(5), 431-443.

[110] Schroeder, A., \& Kotlarsky, J. (2015). Digital resources and their role in advanced service provision $-a$ VRIN analysis. Paper presented at the Spring Servitization Conference.

[111] Shostack, G. (1977). Breaking free from product marketing. Journal of Marketing, 41(2), 73-80.

[112] Sjödin, D. R., Parida, V., \& Kohtamäki, M. (2016). Capability configurations for advanced service offerings in manufacturing firms: Using fuzzy set qualitative comparative analysis. Journal of Business Research, 69(1), 5330-5335.

[113] Sjödin, D. R., Parida, V., \& Wincent, J. (2016). Value cocreation process of integrated product-services: Effect of role ambiguities and relational coping strategies. Industrial Marketing Management, 56, 108-119.

[114] Slack, N. (2005). Operations strategy: will it ever realise its potential. Gestão \& Producão, 12(3), 323-332. 
[115] Smith, L., Mickey, H., Dr Nigel Caldwell, D., Maull, R., \& C.L. Ng, I. (2014). Servitization and operations management: a service dominant-logic approach. International Journal of Operations \& Production Management, 34(2), 242-269. doi:10.1108/ijopm-022011-0053

[116] Song, W., \& Sakao, T. (2017). A customization-oriented framework for design of sustainable product/service system. J. Clean. Prod. , 140(3), 1672-1685.

[117] Sousa, R., \& Silveira, G. J. C. (2017). Capability antecedents and performance outcomes of servitization. International Journal of Operations \& Production Management, 37(4), 444-467. doi:10.1108/ijopm-112015-0696

[118] Spohrer, J., \& Maglio, P. (2008). The emergence of service science: toward systematic service innovations to accelerate co-creation of value. . Prod. Oper. Manag., 17(3), 238-246.

[119] Spring, M., \& Araujo, L. (2013). Beyond the service factory: service innovation in manufacturing supply networks. Ind. Market. Manag. , 42(1), 59-70.

[120] Suarez, F. F., Cusumano, M. A., \& Kahl, S. (2013). Services and the business models of product firms: an empirical analysis of the software industry. Management Science, 59(2), 420-435.

[121] Tabibzadeh, R., \& Wireman, D. (2003). Value chain collaboration. Aircraft Engineering and Aerospace Technology, 75(6).

[122] Takeyama, M., Tsukui, K., \& Shibata, Y. (2014). Resource oriented service ideation: integrating $S$-D logic with service design Paper presented at the Fourth Service Design and Service Innovation Conference, United Kingdom.

[123] Tukker, A. (2004). Eight types of product-service system: eight ways to sustainability? Experiences from suspronet. Bus. Strategy Environ., 13, 246-260.

[124] Tuli, K. R., Kohli, A. K., \& Bharadwaj, S. G. (2007). Rethinking customer solutions: from product bundles to relational processes. Journal of Marketing, 71(3), 1-17.

[125] Ulaga, V., \& Loveland, J. M. (2014). Transitioning from product to service-led growth in manufacturing firms: emergent challenges in selecting and managing the industrial sales force. . Ind. Market. Serv. , 43(1), 113125.

[126] Ulaga, W., \& Reinartz, W. J. (2011). Hybrid offerings: how manufacturing firms combine goods and services successfully. . Journal of Marketing, 75(6), 5-23.

[127] Vandermerwe, S., \& Rada, J. (1988). Servitization of business: adding value by adding services. Eur. Manag. J., 6(4), 314-324.

[128] Vargo, S. L. (2008). Integration and value creation paradigmatic traps and perspectives. J. Serv. Res., 11(2), 211-215.

[129] Vargo, S. L., \& Lusch, R. F. (2004). Evolving to a new dominant logic for marketing. Journal of Marketing, 68(1), 1-17.
[130] Vargo, S. L., \& Lusch, R. F. (2008). Service-dominant logic: continuing the evolution. Journal of the Academy of Marketing Science, 36(1), 1-10.

[131] Vargo, S. L., \& Lusch, R. F. (2014). Service-dominant logic: What it is, what it is not, what it might be. In The service-dominant logic of marketing (pp. 61-74). Routledge.

[132] Vargo, S. L., \& Lusch, R. F. (2018). The Sage Handbook of Service-Dominant Logic: SAGE Publications Ltd.

[133] Vendrell-Herrero, F., \& Wilson, J. R. (2017). Servitization for territorial competitiveness: taxonomy and research agenda. Competitiveness Review, 27(1), 2-11. doi:10.1108/cr-02-2016-0005

[134] Visintin, F. (2012). Providing integrated solutions in the professional printing industry: the case of Océ. Computers in Industry, 63(4), 379-388.

[135] Visnjic, I. K., \& Van Looy, B. (2013). Servitization: disentangling the impact of service business model innovation on manufacturing firm performance. Journal of Operations Management, 31(4), 169-180.

[136] Wilson, T. L. (1999). International after-sales services. Journal of Global Marketing, 13(1), 5-27.

[137] Windahl, C., \& Lakemond, N. (2006). Developing integrated solutions: the importance of relationships within the network. Industrial Marketing Management, 35(7), 806-818.

[138] Wise, R., \& Baumgartner, P. (1999). Go downstream: the new profit imperative in manufacturing. . Harv. Bus. Rev., 77(5), 133-141.

[139] Zarpelon Neto, G., Pereira, G. M., \& Borchardt, M. (2015). What problems manufacturing companies can face when providing services around the world? . Journal of Business \& Industrial Marketing, 30(5), 461-471.

[140] Zghidi, A. B., \& Zaiem, I. (2017). Service orientation as a strategic marketing tool: the moderating effect of business sector. Compet. Rev., 27(1), 40-61. 